\title{
MOTIVATED MARKETS: Instruments and Ideologies of Clean Energy in the United Kingdom
}

\author{
JOSHUA RENO \\ Goldsmiths College, University of London
}

“Green” or “natural” capitalism (Foster 2002; Hawken et al. 1999; Kovel 1999) is typically concerned with the reconciliation of ecological and economic values. By green capitalism, I refer to forms of political economy that seek to appropriate the reproductive potential of biomaterials or to nurture and sustain such potential or both (see Hayden 2003; Helmreich 2008; Rajan 2006; Sodikoff 2007). These aims are typically thought to be troubled in one of two ways: either by the difficulty (if not the impossibility) of establishing metrics to adequately account for the "true value" of nature, or by what Marxian ecologists refer to as a metabolic rift that progressively divides capitalist industry and labor from the nonhuman environment on which they depend (see Clark and York 2005; Foster 2000; O'Connor 1997). In this article, I explore market devices that are meant to establish such metrics and bridge such rifts through the promotion of renewable energy as a commercially viable substitute for fossil fuels.

Efforts to promote "clean energy economies" are founded on the belief that capitalism should be motivated by the real limitations and possibilities of the earth, not by the exchange of purportedly abstract or fictitious representations of value. ${ }^{1}$ Those committed to the pursuit of clean energy seek to plan economies around resources that avoid the grave social and environmental costs of fossil fuels. Unlike the planet's vanishing oil reserves, sunlight, wind, and waves are relatively plentiful, regenerate quickly, and when exploited typically have a reduced ecological impact. For this reason, the promotion of renewable energy is increasingly part of the policy 
agendas of industrial nations and environmental groups, fostered by experiments at once technical, economic, and governmental.

To grapple with these ongoing efforts of social transformation, I focus on the Renewables Obligation (RO) of England and Wales, which involves the creation of a government-sponsored market in virtual "renewability" to subsidize the production of renewable energy and generate demand for it. Although there are many ways of accomplishing these goals, Euro-American economists and government officials tend to favor polices that utilize financial incentives. Like markets in carbon offsets, renewable energy policy in the United Kingdom is a form of neoliberal governance; rather than merely force compliance it seeks to motivate individuals through financial incentives. Such policies rely on assumptions about how individuals can be motivated to act in accordance with policy directives. Economic interests, it is thought, can be harnessed as a political mechanism to bolster green virtues; the assumption being that the actors in question possess a desire for wealth that can be channeled into reform: Homo economicus and Homo ecologicus are made one through market design.

According to the material sociology of finance, broadly associated with the work of Michel Callon (1998, 2009) and Donald MacKenzie (2009) among others, individual actors in a market can approximate the "economically rational" selfinterest described by economists with the help of the various technical devices they have at their disposal. A person at a grocery store, for example, is not alone, but may be accompanied by an itemized list, a calculator, coupons, signs advertizing special deals, price tags, a receipt, and so on. "Interests are not given," writes MacKenzie, "they are calculated" as part of larger sociotechnical arrangements of persons and an assortment of market devices (2009:25). I discuss the relationship between participants in the United Kingdom's renewable energy sector and different environmental and economic devices that facilitate their actions, focusing in particular on the different ways market devices channel environmental and economic motivations as well as reshape them into new and potentially alienating forms.

I examine the RO primarily from the perspective of small-scale generators, who make up nearly two-thirds of the renewable energy facilities in the United Kingdom, but are responsible for less than one percent of renewable energy produced (Ofgem 2009:37). I begin by discussing the beginnings of the renewable energy sector among U.K. farmers and the transformations brought about through market-based policies. I focus on farmers, in particular, because their experiences illustrate the complex intentions associated with making the environmental 
economic. In the United Kingdom, farms and farm animals have recently served as critical sites for the representation and governance of the most pressing environmental issues, including genetic engineering (GM crops, cloning), climate change (methane emissions), and global pandemics (bovine spongiform encephalopathy, foot-and-mouth disease). For some, waste-to-energy digesters promise to transform a dangerous pollutant (animal wastes) into an environmental good (renewable energy) at a time when both environmental credibility and economic security are increasingly uncertain.

I demonstrate that renewable energy producers, including U.K. farmers and energy suppliers and traders, participate in the market in renewables in ways that are out of sync with the predictions of policymakers. To explain the significance of green certificates for RO participants, I draw on the notion of social payment (Guyer 2004; Maurer 2007), which highlights the variety of ways that these virtual commodities are accounted for, whether as forms of wealth, moral currency, regulatory obligation, or risk.

Although participants in the renewable market demonstrate a wide variety of economic actions and motivations, market devices record their transactions as examples of "competitive exchange" and "self-interest," thereby reproducing authoritative facts about the market in accordance with neoliberal accounts. Contemporary tools of economic reflection and intervention emerged in the early 20th century alongside the increasing dependency of capitalist democracy on fossil fuels (Mitchell 2009:416). Therefore it is not only the effects of economic reforms, but also their translation into economic expertise that requires analysis.

Following Timothy Mitchell (2005) and Webb Keane (2008), I emphasize the role of market devices, especially renewable energy meters and auctions, in furthering neoliberal models of the economic, as well as providing a means of contesting them. Such devices not only help market participants calculate their interests and make economic decisions, as Callon and MacKenzie suggest, they also make the motivations of those participants calculable as objects of economic knowledge. The economic "facts" that result, I argue, frame economic action in a narrow way that shapes the reflections of renewable policy experts as well as their critics.

My goal in this article is not to advocate a particular method of energy reform. Rather, I want to explore the means by which green markets are thought possibleand by extension, new forms of capitalism - as well as the implications this has for the economic as a form of expert knowledge and social practice. In the conclusion, I discuss the significance of models of the person in the creation of renewable energy 
and climate change policies more broadly, arguing for more appreciation of the importance of uncertainty, ambivalence, and the incongruities of social action.

\section{GROWING AND GOVERNING ENERGY}

In summer 2008, I toured the U.K. countryside with James Murcott, ${ }^{2}$ an expert on anaerobic digestion or "digesters," visiting some of the 35 facilities he had helped develop. "Fossil-fuel farming is a dead-end road," he told me, and abandoning this path does not mean devoting farms to a new purpose - planting "energy crops" to create biofuel, for instance - but recognizing the untapped potential of their wastes. Designs vary, but typically digesters involve a vessel into which various biomaterials are pumped, after which they are mixed together and broken down to form two substances: a fertilizer high in nitrogen and methane, a combustible biogas.

For Murcott, such technology realizes a dream of improved agriculture: "[It] gives you energy as a by-product, but it gives you odor control, it gives you better nutrient management. When you take the carbon out of the waste stream, you are making the nutrients more available for fertilizer." Like others, Murcott became interested in renewables during the energy crisis of 1973-74, "We had a flood of books, people that set about gathering information that would help us. There were books about wind energy, solar, and a little on digesters.” Murcott preferred the reliability of digesters: "The wind blowing, the sun shining, tends to be unpredictable; that pile of muck in the yard is very predictable." Following examples from India and China, he built a prototype "baby digester" for his fatherin-law's chicken farm, a $2 \mathrm{~m}^{3}$ unit just big enough to produce gas for cooking.

In the mid-1970s, Murcott formed a company with his wife's cousin that would become the primary digester supplier in the United Kingdom. He later formed a different company to focus exclusively on farm digesters, with the assistance of the U.K. Ministry of Agriculture, Food, and Fish (MAFF), which distributed digester grants to encourage rural diversification. One of his clients was Phillip Nelson, a Welsh farmer who wanted a digester to heat his houses and dairy operation, improve his fertilizer, and reduce his dependence on fossil fuels. A small agricultural university used a large digester for their livestock. Another Welshman used the technology to "go organic" to improve the quality of his cheese (see Figure 1). Murcott's plants were still running as many as two decades later.

But the political landscape of renewables was changing. In the mid-1990s, MAFF stopped its grant program and another company with controlling interest liquidated Murcott's digester business. The grants had been replaced with a 


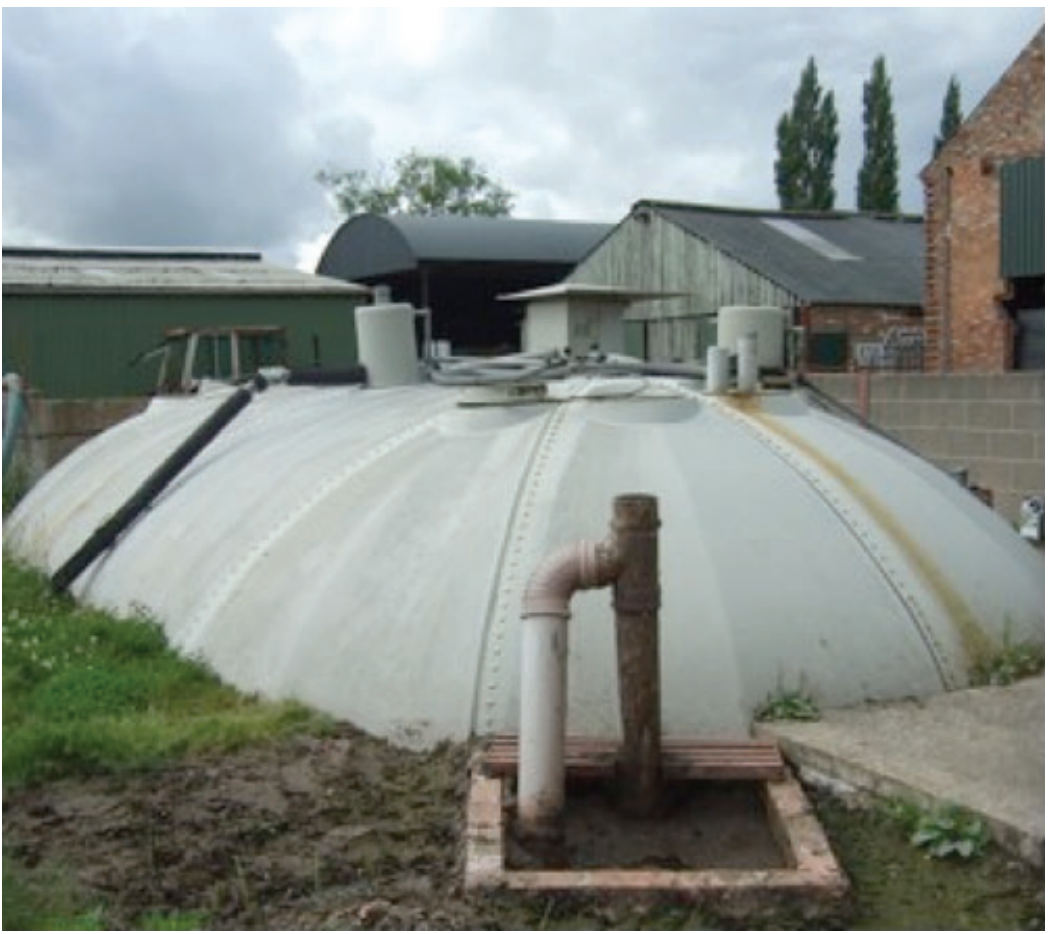

FIGURE 1. A biological digester designed by James Murcott.

market-based program to encourage the production of renewable energy for sale. In 1990, the conservative government decided to subsidize renewables (particularly nuclear power) as part of its bid to privatize the energy sector (Mitchell 2000:286). Europe's first such initiative, this initial policy was managed like a competitive grant: the government would order a specific quantity of renewable energy, and then select the lowest bidders for different technology "bands" (e.g., wind, solar, etc.). Regional electricity companies were obliged to purchase all the renewable energy projects in their area at a premium price. Suppliers were obliged to purchase all the energy from projects awarded grants.

As concerns about climate change and energy security mounted among interest groups throughout Europe, more procurement schemes emerged. Prior to the deregulation of EU energy markets, the policy most often implemented by European governments was some variation of feed-in tariff (FIT), such as Germany introduced in 1991. Like the initial U.K. plan, FIT obliges regional suppliers to buy from renewable generators at a fixed price but makes this available to any generator and has no quota (Ringel 2006:6). Although costly, FIT proved more successful at 
procurement - by 2003 FIT was responsible for at least 84 percent of the power generated from wind in the European Union (Meyer and Koefoed 2003:598).

For these and other reasons, in 2001 the U.K. New Labour government introduced the Renewables Obligation. The RO retained quota obligations, as well as competition: energy suppliers were obliged to invest in a growing number of renewables annually (specified as a specific fraction of their total energy output) or pay a "buyout fee" for every megawatt hour (MWh) they fell below their obligation. Fulfillment of this obligation is demonstrated by purchasing Renewables Obligation Certificates (or ROCs). Each green certificate or credit is a virtual representation of one MWh of renewable electricity generated in the United Kingdom. From this demand for renewable credits arises a supplementary market, which provides a separate income to generators for the virtual "renewability" of the energy they produce (see Figure 2).

The complex value of ROCs adds a further "gaming" element to encourage suppliers to exceed their obligation (Mitchell et al. 2006:300). At the end of every obligation period, money from the buyout fund (collected from all those who failed to meet their full quota) is "recycled" back into the value of each accumulated renewability credit, thus ideally rewarding suppliers who overachieve in producing or buying green energy at the expense of others.

In 2008, for example, the obligation was for 7.9 percent of energy supplied in England and Wales to be from renewables (22 million MWh), increased from

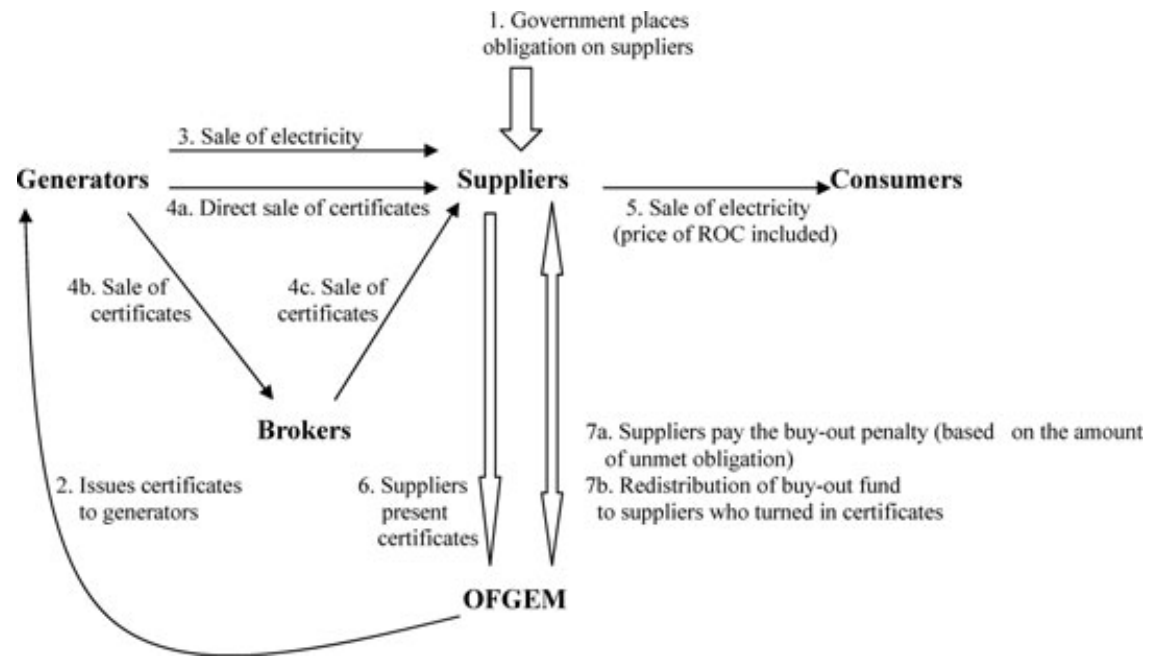

FIGURE 2. The market in ROCs. 
6.7 percent in 2007. Thirty energy suppliers turned over 14.5 million ROCs to the Office of Gas and Electricity Markets (Ofgem), satisfying roughly 64 percent of the total obligation, which meant that the buyout fund from noncompliance was high (more than $£ 280$ million) and the ultimate value of each credit increased to $£ 52.95$. Because there is more financial incentive to exceed the obligation than to pay the buyout, ROCs are thought to encourage further renewable investment.

The RO diagrammed above serves as a model of moral accountability. As with the conservative government's plan, energy supply companies are held directly responsible by the government for financing a clean energy economy. A renewability credit serves as a record of who has contributed what amount to the growth of clean energy. ${ }^{3}$ Other social exclusions become apparent at the technical level. Renewable projects can only earn ROCs if they seem viable enough to attract sufficient outside funding and progress through the difficult planning phase. For this reason, more established companies in Western and Northern Europe are increasingly attracted to the United Kingdom, where they can successfully compete for contracts.

The digesters that are now built on U.K. farms reflect a change from 20 years ago, indicating that market-based approaches are reshaping motivations from consumption to production of energy. New plants tend to rely on German technology more than Murcott's designs. Alan Sloan's digester is one example. He sought out a German partner to demonstrate and distribute digester technology from his farm in Dorset. With its backing, he installed a $2,800 \mathrm{~m}^{3}$ digester to process his corn and cow slurry into renewable energy and credits. Even some of Murcott's former clients have decided to sell gas. Nelson, one of the Welsh farmers introduced above, invested in an innovative three-stage digester, also of German origin and built around the plant Murcott installed, primarily to enhance energy production for ROCs.

Through market-based initiatives, an alternative model of renewability focused on the farm as an organic process is losing favor to one focused on the development of new sources of energy for the national grid. Murcott's approach to digesters tends to emphasize saving rather than producing energy. Digesters, he argues, should mimic the economical makeup of animal bodies:

Are you familiar with a cow? A cow plucks the grass using its tongue and puts it into its first stomach, where it undergoes biological breakdown. It doesn't chew it. It then sits on the ground and ruminates, which means it regurgitates its food and macerates. So it macerates it after the first stage of digestion, and that means it takes less energy for the maceration stage. A chicken eats its food 
whole and has a macerator in its gizzard that actually helps it to break down its food internally.... And you can apply all of these things to your digester design. ... I think you'll find that pre-digestion is going to become a more preferred way of doing things. It requires less energy.

According to this model, farm production and energy generation from waste ought to be integrated as if part of a living organism. For Murcott, this began as a way to adapt Indian designs to a cooler environment; to address the heating and mixing demands of U.K. farms, gas is circulated back into the digester to drive the mechanical maceration of material. Similarly, excess gas is pumped into the farmhouse to be used for cooking and heating, because that is seen to be more energy efficient than pumping it into a grid to contribute to the nation's renewable quotas.

The digesters based on German designs represent a different approach, which interrupts the recycling of energy back into the farm. After Sloan's digester was fully commissioned, it could not send power to the grid or register ROCs because the tank was too acidic, threatening the engine with corrosion. Until a neutralizing base could be added, Sloan was losing money on an "insecure" product from the standpoint of energy production, although it was perfectly usable as a source of heat. But Sloan didn't finance his digestor for heat. Neither did the Welsh farmer Nelson; in his new German digester, where gas had once been channeled to a boiler, heat exchangers now draw waste heat from the engine as it converts methane into electricity. This way the ROC meter registers as much gas as possible, while heat use is subordinated to the generation of electricity.

In some ways, this shift to production for the grid introduces new forms of alienation that can interrupt daily life on the farm as well. For energy to be traded, whether as a commodity or credit, generators need to be connected to energy consumers drawing from the national grid. Rural digesters are typically too small to connect to the grid the normal way; instead, they must transmit energy through the distribution network. But network connection is not so simple. In Sloan's case, the local water board identified the location of a water main incorrectly, and a pipe was mistakenly ruptured, shutting off water to 44 homes and four farms for several hours.

Other tensions arise through the technology, showing its ability to frustrate some of the agricultural values that Murcott's more organic design was meant to realize. It is evident that reorienting the digester toward energy production has changed Nelson's farm in Wales, and not entirely to his liking. During my tour, 
he moved freely through every area, around cows and through gates, excitedly explaining his plans to digest hay with slurry, pointing out what equipment needed replacing or describing the gas potential of chicken litter. But toward the end of the visit, at the farm's edge, Nelson stopped to complain that he was forbidden from entering the locked, fenced-off shack where the electrical transformers connect to the grid. Connecting to the distribution network meant inviting an alien structure into an intimate space, enclosed to "protect" him from the high voltage generated from his own animals, creating a spatial analogue to the conversion of his biogas into an alienable product.

Nelson's farm has borne witness to the shift in the U.K. from renewable energy as farm management to renewability as a tradable commodity. For Sloan and his newly built digester, establishing connections to the grid is an opportunity to prove the value of digesters to his neighbors - some of whom remember well his past interest in GM crops. When I visited his plant, one of the pipelines was left uncommitted so that it might one day provide free gas to the community. As will be discussed in the next section, revaluing energy through market instruments like ROCs does not foreclose investment in the moral and material improvement of farms, even as it reshapes how they can be accounted for.

\section{ACCOUNTING FOR ROCS}

Countless anthropological studies have challenged the characterization of financial instruments (wages, taxes, bonds, derivatives, etc.) as merely asocial forces of pure rationalization and commodification (Bloch and Parry 1989; Lemon 1998; Akin and Robbins 1999; Maurer 2005). In the United Kingdom, ROCs coexist with a multiplicity of social actions and motivations, interests and responsibilities. As the British countryside endures profound change, farming involves wider debates that implicate not only plants and animals, family and neighbors, but regulators and the global food trade. The anticipation of green credits recasts decisions about the management of farms in a variety of ways, revealing the complex motives out of which the emergent renewability market is derived, as well as conceptions of the economic more broadly.

Following the work of Jane Guyer (2004), Bill Maurer argues that some forms of financial action, which he calls "social payments," fall outside the sphere of exchange altogether: "[A] vast number of things financial ... stand aside from the quantitative machinery that many have taken to be capitalism's hallmark. Rather, they involve payments, efforts to avoid payments, the consequences of those efforts, and the creation and manipulation of debt" (2007:127). Such payments 
are more broadly "social" because they involve a debt relationship and the creative hesitations and manipulations this can entail. David Graeber (2011) points out that debt cannot be reduced to relations of exchange or reciprocity, but in its purest expression coincides with relations of hierarchy. Taxes, for example, are not about an exchange between equal partners, but about a political subject giving an obligatory payment, one that cannot be finally repaid during one's lifetime. And yet, this obligation can be deferred and manipulated; there are tax "write offs," “evasions," and “cheats.” I draw on Maurer and Graeber as a reminder that financial instruments are about more than actively desired and accumulated forms of wealth, but ambivalently accounted for and negotiated payments.

ROCs, like connections to the national grid, offer new ways of calculating for the day-to-day business of farm management. Nelson claims "environmental" concerns as the primary reason he renovated the original digester Murcott designed. He expressed anxiety about climate change: "If we mess up the climate, there'll be no hiding place-we're all in this together." In this sense, ROCs stand for environmental responsibility. In the same way, "carbon" is not only tradable as a commodity but increasingly works as a form of moral currency in ecological discourse, a way of accounting that stands in for one's willingness to do something about environmental degradation. Nelson's sense of environmental care through digester technology is not only about moral accounting but practical management of the farm, as he puts it "getting better use of the fertilizer value of those manures." The best evidence of environmental impact, from his perspective, is that he's "never had such thick and strong grass" as he is getting from the fertilizer spread on his fields. ROCs were meant to enable this further integration of farm and digester.

Unlike the Murcott design, new German digesters force farmers to consider their financial circumstances more carefully. Nelson claims he was "a bit blind" in his pursuit of ROCs at first, with only a rough idea of what to expect regarding costs and financial returns. If so, this seems to have changed over time. When I last spoke with him, Nelson had lost an estimated $£ 70,000$ because of a technical difficulty establishing proper electrical balance between his generator and the grid. He has also found it challenging to find a good price for the food waste they buy, which is not only a good additive to the digester but a popular source of pet food. Nelson's biggest concern, however, is what he was offered for his ROCs $-4.5 \mathrm{p}$ per $\mathrm{kWh}$, which has declined a further $0.9 \mathrm{p}$ with falling energy prices. Even doubled, this is far less than he anticipated.

Yet, Nelson showed little interest in selling his ROCs for potentially higher value on the open market or at auction, in keeping with the government's incentive 
program and its presumption of self-interested subjects. When I mentioned the possibility in response to his financial woes, he shrugged, as if it were the sacrifice he was making that he was invested in or thought more worth discussing with a social scientist. This sense of sacrifice and struggle is a familiar experience for smallscale farmers in the United Kingdom, whose way of life is sustained by grants, loans, and subsidies season to season. Like Nelson's experiences with ROCs, these various social payments by no means constitute a comfortable relationship with the state. In the aftermath of recent epidemics affecting livestock and the 2004 ban on foxhunting, ${ }^{4}$ a level of mistrust has permeated farming communities concerning government oversight. As competition with foreign producers grows, efforts to convince the government and general public that domestic farming is worth supporting have taken the form of collective action, as when pig farmers picketed Parliament to raise awareness of their economic difficulties in 2008.

Similar to pig farmers, dairy farmers like the Nelsons have faced financial pressure from more cheaply produced agricultural goods abroad. At best, it is thought, digesters and ROCs should contribute to their continued survival within this competitive climate. Nelson now suspects ROCs no longer can, and he wants to switch to the United Kingdom's new tariff program, introduced in 2009 for smaller generators, which obliges suppliers to purchase renewable energy at a fixed rate of $11.5 \mathrm{p}$ per $\mathrm{kWh}$. Although the new law allows midsize generators (between $50 \mathrm{kWh}$ and $5 \mathrm{MWh}$ ) to transfer from ROCs to FITs as well, this does not apply if generators are locked into a contract, as are the Nelsons'. Nelson blames Ofgem, in part, for its ineffectiveness and has been asking his members of Parliament to change the rules. For him, ROCs are like a bad grant that should be replaced with a new one, precisely because they are thought of as a means to secure a valuable way of life, one that is important to the government as well as to families.

Sloan has his own methods of accounting for AD and ROCs. Always interested in promoting his farm, he appears in a YouTube video at a European climate change conference in 2009. In the clip, a succinct introduction to his digester reveals a different position from Nelson's:

The economics, I guess, is the principal reason we actually undertook the venture. ... The output of the plant is $370 \mathrm{kWh}$, and we look to run that for 8,000 hours a year, so with a current rate that's available to us in the UK of 14.5 pence per $\mathrm{kWh}$, or 17 eurocents, we're looking to turn over 422,000 of electrical income per year. 
Yet, his next statement echoes that of his Welsh counterpart: "it was a way to add value to the produce we grow on the farm."

Some of the spin-off benefits that have come out from [the digester] have been the fact that the digestate that comes out ... has a much higher nitrogen value ... it also doesn't smell ... so we don't get rejection problems with cattle feeding behind it, so that's enabled us to make a saving of 60 to 70 percent on our imported nitrogen fertilizer, which means a direct cash saving.

Like Nelson, Sloan's estimation of "value" is part of a method of accounting that sees the farm as a total process of growth and transformation. But for him, this involves more precise calculations of energy and cash gained and lost.

Ultimately, the main purpose of his digester is to serve as a showcase for his German technology. This shapes Sloan's view of ROCs, which he sees not as assets but, rather, as risks to be managed carefully. The problem, he suggested to me, is that farmers tend to be risk averse:

Farmers are bloody conditioned to getting grants. So you can tell people how much return on investment they'll make, because of the double ROC, and then the next person will say, "Are there are any grants?" And I said, "Say I give you a 15 to 20 percent return on your investment, how much more do you want?" It's a green premium, which is only 15 percent of the price you get, that's where the incentive is. [Imitates a rural farmer.] "Well, I'd rather have 40 percent up front and a lower price at the end," because they just see it as derisking it. They see it as someone else's job to take the risk.

Taking the risk here means taking the ROCs. Sloan often tells prospective clients that they should disregard double ROCs from their estimates altogether, to avoid confusing risk for reward but also as a hedge against potential policy changes. Like Nelson, his position on ROCs has only become more ambivalent with the release of the new FIT law. This is because the value of ROCs is not set within the market but is further mediated by competing regulatory incentives.

It is perhaps for these reasons - relational interpretations of ROCs as grants given, risks shared, or policies enforced - that small-scale generators subject to the $\mathrm{RO}$ are more likely to accept long-term contracts, or power purchase agreements, that bundle their green certificates with electricity, in effect providing the value of the ROC up front and offloading risk and reward to the energy supplier. As Sloan indicates, it is not simply about eliminating risk but maintaining familiar forms of obligation. A grant up front (which many are likely to have depended on in the 
past) serves as a familiar and dependable social payment, a fee for working in an undeveloped but important sector.

Although it may be that small generators are more attuned to the kinds of accounting I have described thus far, the social payments or debt-relations occasioned by participation in the ROC market are similar for large renewable generators and energy suppliers. Most have tended to hoard renewable credits, rather than trading in large volumes as expected (Mitchell et al. 2006:302). Cara, a renewable energy broker, described this to me as another accounting maneuver. It is why, for instance, her company convenes its ROC auction on a monthly basis, allowing suppliers to adjust their approach to the RO throughout the year. Because many suppliers own their own renewable generators, they too are vulnerable to planning and technical difficulties. As Cara put it, "What happens if they've been banking on getting 500,000 ROCs, a wind farm goes down, so they're only going to get 400,000?" At different points throughout the obligation period, companies may seek to purchase extra ROCs quickly or to defer until the deadline, tactics a monthly auction helps make possible. In this instance, suppliers do not see the purchase of appreciating ROCs as an investment opportunity, as intended by the government, but as a form of social payment they are obliged to make.

Deciding how to negotiate the ROC market takes shape in a context of established relations between farmers, energy companies, state agencies, and banks, encouraging the adoption of familiar accounting strategies. At the same time, it entails new forms of obliging and manipulating social payment and debt, crystallized around the experimental moment associated with climate change governance. In the next section, I will explain how these various motives surrounding credits and payments are translated by market devices into an authoritative record of exchange, which generates economic facts for reflexive control and critique of the ROC market.

\section{MARKET REFLECTIONS}

In 2002, the same year the RO was introduced, the EU passed the Renewables Directive. In keeping with the pragmatic ethos of European governance, governments were made responsible for deriving a specified percentage of their energy from renewables - without specifying how (see Barry 1993:316). Within the environmental policy communities of Euro-America, market-based certificates and more directly subsidized tariffs have been the primary regulatory means of replacing fossil fuels with renewable sources. Generally speaking, preference for tariffs or certificates tends to overlap with a larger divide between social democratic and 
neoliberal ideologies of state action, respectively (see Toke 2005:362-63). Thus, TGCs have been favored by the United Kingdom, the United States, and transnational blocs like NAFTA's Commission for Environmental Cooperation and the European Commission, while Canada and much of Western Europe have tended to favor FITs, along with groups like Greenpeace and Friends of the Earth. Such tendencies are indeed revealing, but I would suggest that they are not an ideological given; the apparent necessity or moral appeal of any policy is enacted through the practical technicalities of governance (see Ong 2006).

In this section I document how the moral claims of neoliberal models acquire authority through their material embodiment in particular market devices. In particular, I describe the market devices that create a digital record of ROC transactions and shape the accounts of RO regulators, participants, and critics. Market devices accomplish this by distilling economic "facts" imbued with particular visions of what motivates individuals (self-interest) and how they act in economic situations (through competitive exchange). My approach follows Mitchell (2005) and Keane (2008), both of whom suggest that the objectification of market ideologies into facts and instruments renders them contestable and makes alternative market reflections possible.

By 2001, TGC began to gain popularity in Europe. For one thing, it was believed to be more cost efficient than FIT and to match better with the deregulation of EU electricity markets. But certificates were also preferred because they offer a built-in audit function. Together, green certificates represent the total megawattage that is allocated to generators, traded, and eventually turned over to the regulator by suppliers. At the generator level, this audit mechanism is embodied by the ROC meter (see Figure 3). Each meter possesses a unique accreditation number; as electricity is generated, it is recorded as one certificate per MWh (or two for "emerging" technologies like digesters).

Despite their seemingly neutral numerical operation, ROC meters are central to authoritative interpretations of the green certificate trade. ROC figures are ultimately submitted to Ofgem, which can then compare the debits allotted to suppliers with the credits they return at the end of each obligation period. In this way, renewable plants distribute energy and information in parallel, providing a mode of double-entry bookkeeping that documents actions within the renewable sector. Mary Poovey (1998) describes the emergence of double-entry bookkeeping in early modern Italy as not only a means of monitoring and balancing accounts but a form of moral persuasion. Recording financial transactions in this way made them appear undeniable and transparent, bestowing on them an aura of facticity. 


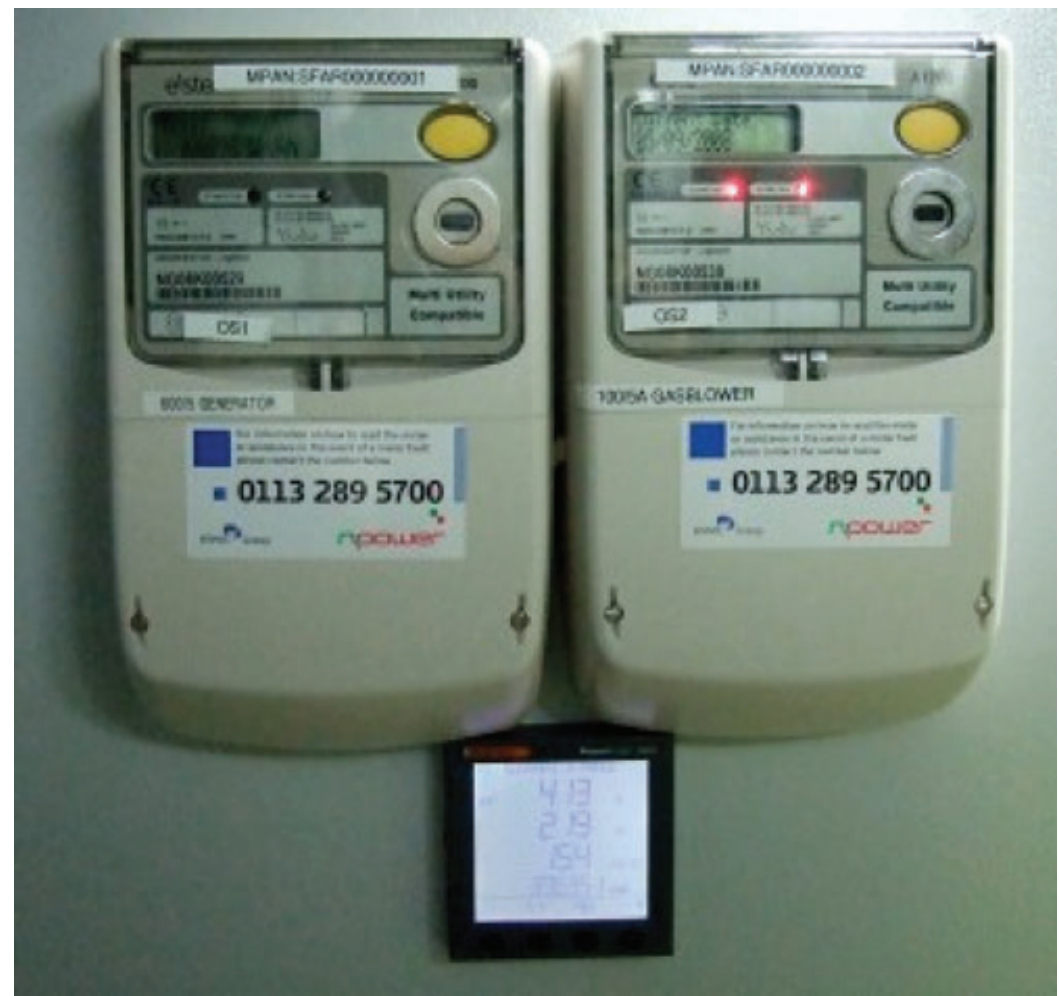

FIGURE 3. ROC meters for a digester.

Because of the epistemological significance of double-entry bookkeeping as a source of demonstration, Poovey situates it as a precursor to the "modern fact." The virtual market in renewable credits is essentially a market in facts — but facts for whom?

According to Mitchell (2005), the way that "the economy" is materially and politically formatted - that is, as a knowable thing composed of distinct monetary exchanges - allows for the performance of expert knowledge. The RO presents the virtual production, exchange, and return of renewable credits, like entries in a public ledger, and the design of EU directives makes such accountability highly desirable. Because they are equipped with numerical representations of the market as a collection of transactions, state actors and policy experts can predicate about the growth of the United Kingdom's renewable sector or the RO's ability to meet European targets. The RO makes renewability legible, creating a pool of data at annual intervals, giving regulators the ability to routinely audit the market (to estimate the price per $\mathrm{ROC}$, the amount of renewable energy created, the kinds 
of technologies promoted, etc.). Consequently, it also provides the flexibility to make necessary adjustments as the EU's target deadlines approach.

The market facts distilled from ROC meters also inform the adjustments made by leaving out the hesitations and negotiations characteristic of certificate circulation and facilitating the interpretation of ROCs as desirable wealth and the motivations of market actors as competitive, self-interested exchange. It is based on such conceptions of the economic, for example, that emerging technologies were thought best supported by doubling the ROCs they receive.

Moreover, this interpretive frame is meant to circulate publicly, encouraging market participants to represent their own economic action as guided by selfinterest. Initially skeptical of AD, the owner of a large composting operation in Dorset characterized his decision making in this way: "At the end of the day, I'm a tart. There's the technology side of it as well, which was a bit iffy. ... With the advent of two ROCs, it certainly tips the balance. ... The extra financial rewards [make it worth the] gamble." Poovey also suggested that double entry bookkeeping: "generalized rule governed behavior by encouraging merchants and their agents to reproduce in action the orderly logic of the books" (1998:11). In a similar way, renewable certificates reproduce an interpretative frame of self-interest, a policy instrument that translates political targets into personal desire. ROCs are a financial promise, an anticipatory entry in an account balance that persuades people to act as they should.

Spreading such conceptions of economic action represents a fulfillment of an ideal element of market reflexivity that economists call "complete information," which holds that "players" ought to be aware of the moves and motives available to others in the game, particularly those with whom one intends to trade. It is partly for this reason that the facts produced by ROC meters and collected by Ofgem are made publicly available through annual reports in print and online, simultaneously enacting the ideal transparency of a market to its participants and that of a government to its citizens. During the course of my research, a number of informants suggested a popular workshop on the RO sponsored by a consultancy in southwestern England. In fact, some addressed my questions about their experiences by forwarding to me documents they had received during such seminars, which offered clear diagrams outlining the circulation and valuation of ROCs year by year. Diagrams of historical ROC activity are not only informative but performative; they present the market as a series of precise, individual exchanges aggregated into a complete balance sheet. In the process, they also offer moral arguments in support of economistic decision making. Those without renewable 
investments are encouraged to make them; those with ROCs to sell are told of the virtue of interpreting ROCs as liquid assets, whose true value might best be realized through open auctions. ${ }^{5}$

Unlike ROCs themselves, ROC facts travel internationally, animating discussions about the future of renewable energy policy. It has been alleged that green certificates have failed to encourage sufficient investment in the U.K. renewable sector, meaning that utility companies fall short of their obligations by a greater amount each year (Agnolucci 2007:3349). Economic efficiency is important to TGC initiatives: with more investment in renewable energy, more ROCs are generated and demand falls, leading to a lower overall cost per ROC and, ultimately, lower cost to energy customers. Whereas there were enough ROCs available to satisfy 70 percent of the RO in 2005, the number declined to 66 percent in 2007 and 64 percent in 2008 (Ofgem 2009). During that same period, the value of each ROC (taking into account the contribution of the buyout fund) rose by nearly 18 percent.

Is someone responsible for the RO's purported failure? For some critics, ROC bookkeeping records the motives of market participants. A prominent argument among some policy analysts is that energy suppliers are colluding to produce fewer ROCs so as to miss the national target and extract more money from consumers over a longer period, at a lower cost to themselves (Mitchell et al. 2006:302-303; Toke 2005:366). This is difficult to prove, but its appeal is certainly because of the long history of corporate ambivalence and outright resistance to environmental reform in the United Kingdom and elsewhere. Regardless of its veracity, this argument also relies heavily on the apparent facticity of ROC data and the assumptions about economic action such data embodies, identifying destructive patterns visible in the annual records as a product of greed for ROC wealth.

In some instances, auctions are another device that disentangle green certificates from the generative sites they represent and make ROC exchanges appear further "calculated" in the process. From one perspective, auctions serve as a virtual marketplace for ROC sellers and buyers to locate one another and, it is presumed, find a more competitive price. In this sense, they represent a market within a market, another register reflexively responding to and shaping the overall RO. One of the more recent auctions, E-ROC, was created by the auditing body set up by energy supply companies to oversee the competitive grants of the United Kingdom's original renewable policy. Operating four times a year, E-ROC is a blind and highly automated online auction. The site disentangles credits from generators, reducing bundles of ROCs to a fluid "lot," connected only to specific ROC meter 
accreditation numbers. For buyers, the whole process is reduced to an anonymous exchange registered on separate computer screens, suppliers outbidding one another for a digital commodity in limited supply.

Although disembedding fragments of economic reality is an important aspect of the material operation of online exchanges and energy meters, in actuality market devices are capable of eliciting very different reflections on the market. In Poovey's account of the development of double-entry bookkeeping, settled accounts stood for the personal integrity and general virtue of Italian merchants. A stigmatized social class, merchants relied on bookkeeping as a way of managing impressions of their moral personhood (Poovey 1998:55-56). Of course, in the intervening centuries there has been a strong tendency to read "interests" as the prevailing source of individual motivation, in place of "passions" and "virtues" (Hirschmann 1977; Pocock 1975). But accounting instruments are still capable of occasioning alternative ideas of economic action.

An alternative ROC auction was developed by a private consulting firm I call "ExchangeRight" with considerable renewable investments. Cara, the energy trader introduced previously, is one of their employees. According to her, the auction filled a noticeable gap in the RO:

How we started ... was by building up a number of ROCs, say on a sixmonthly basis, then going to a supplier. Because the supplier wouldn't buy 500 ROCs from [the generator] — it's not worth their while doing all of the admin - so we'd collect the ROCs up and then we'd sell them. But very quickly, we went from a couple of hundred to like this [whistles] . . . and then we suddenly realized that ... we should be doing an auction.

To Cara, ExchangeRight is opposed to the E-ROC auction as more than just a competitor; she questions its legality and speculates that it might tend to favor the energy supply companies that fund it. ExchangeRight, she claims, is more committed to making the ROC market "fair" than fluid, which is reflected by its auction. The bidding process is handled predominantly by phone. ExchangeRight representatives negotiate directly with top bidders to make sure they receive the volumes they want at a price advantageous to the generators. For Cara, part of the benefit of such a process is that all parties can be happy with their transactions. Perhaps it is more accurate to say that, because the exchange is more personalized, signs of "happiness" are rendered legible within the auction's interpretive frame.

The conflict between auctioning practices, like those dividing alternative ways of accounting for ROCs or environmental reform, reveals the heterogeneous 
influences that give shape to the market in renewability. To the extent that only some conceptions of the market gain traction as authoritative or necessary, it is in part because of the work accomplished by the market devices and financial instruments, whether grid connections, green certificates, ROC meters or auctions, all of which instantiate particular visions of the economic. But this does not foreclose alternative visions from taking hold.

\section{CONCLUSION}

There is clearly an elective affinity between the shared desire of government and the energy industry to make the "renewability" of energy tradable as a virtual commodity and the explosion in power broking that arose from the deregulation of electricity markets during the late 1990s and early 2000s. The innovation of credit schemes for renewable energy, or carbon emissions, makes sense at a time when new and highly profitable market forms were being derived from energy trading and risks were operationalized into financial instruments, whether as hedges against market loss or forecasted environmental catastrophes. Similarly, in the face of widespread loss of faith and growing concern surrounding global financial instruments, it is telling that the U.K. government has now introduced a German-derived tariff scheme to supplement the RO, as if admitting the limitations of the market-based approach.

Turning renewability and carbon into tradable commodities is meant to make environmental goals calculable as financial incentives, bringing individual motivations in line with ecological imperatives. Keith Hart writes, "How do we bridge the gap between a puny self and a vast, unknowable world? The answer is to scale down the world, to scale up the self or a combination of both, so that a meaningful relationship might be established between them” (2007:16). Such procedures require scalable models of the world and of the person. Arguably, debates over climate change science and policy have focused much more on the former. Scaling up individual actors through economic incentives, I have argued, relies on the assumption that selves are fundamentally driven by a desire for wealth. Thus, green credits are not merely instruments that allow participants in the energy sector to calculate interests; they produce and circulate representations of those participants as self-interested, in keeping with neoliberal ideology.

The success of this ideology is evident in the reflections that predominate when market-based policies fail to produce expected results, as when energy suppliers or producers interpret renewable certificates as social payments. Interestingly, Donald MacKenzie notes the same behavior among carbon traders. "Instead of treating 
a carbon market as a profit opportunity, most [treat] the new and unfamiliar scheme ... as a compliance matter" (2009:174-175). According to him, these market participants still "have to be 'taught' to behave as economically rational agents" (MacKenzie 2009:174-175). The problem is that, whether one is talking about cap and trade or the Renewables Obligation, companies are accustomed to identifying government policies as a form of negotiable obligation; a credit might as well be a tax. Others suspect the motives of carbon emitters and energy suppliers, whom they claim are attempting to sabotage renewable energy and carbon reduction initiatives. However, both supporters and critics of an experimental market rely on the economic facts generated by market devices to reflect on its success and speculate on the beguiling motives of its participants. In this sense, I have argued, these devices not only "teach" participants to calculate; they also “teach" policymakers and economists to imagine participants' motives as calculable according to neoliberal paradigms.

What model of the person should we rely on and what forms of scaling up? I have argued that auctions and certificates admit of multiple interpretations and could just as easily proliferate alternative conceptions of human action and motivation. I would argue that these must account for the uncertainty and ambivalence of those participating in renewable energy and climate change initiatives at all levels. A central incongruity between subjective ideals and social realities constituted the basis for the economic histories written by Max Weber in The Protestant Ethic and the Spirit of Capitalism and Albert Hirschmann (1977). Whereas Weber famously argued that the iron cage of modern capitalism was the unintended product of Calvinist religious practices, Hirschmann focused on early advocates for capitalism, a social transformation that was "earnestly and fully expected to have certain effects that then wholly fail[ed] to materialize” (1977:131). Clearly there are examples of both unintended consequences and unrealized intentions in renewable energy and cap and trade initiatives. But where those Weber and Hirschmann describe at the birth of capitalism are burdened by obliviousness to the consequences of their actions, if anything, attempting to reform capitalism in the face of environmental catastrophe involves a burden of knowledge.

Hirozaku Miyazaki (2003), Annelise Riles (2006), and Douglas Holmes and George Marcus (2006) all discuss the "failure of knowledge" as experienced by those who govern and monitor economies in the aftermath of market crashes. In such contexts, one cannot help but be aware that the most well-intentioned actions can produce unintended consequences while the loftiest of ideals go unrealized. In light of recent market failures and general mistrust of government, as well as the 
sheer complexity of abandoning fossil fuels or stopping climate change, it would be difficult to find someone with complete faith in green markets, whether this is assurance they will make a profit or that the earth will be saved.

Nelson, for one, mocks the significance of his efforts for the climate, "it's like urinating in the sea if you want to raise the sea level" and yet he feels compelled to try. I think Nelson's sentiments are widely shared among those concerned with environmental and economic catastrophe but uncertain of what impact they can make, not because they lack the relevant knowledge but because they know enough to be skeptical. With climate change and renewable initiatives, one can typically identify a sense of disavowal on the part of participants - actions are not earnestly and fully expected to have the intended consequences but, perhaps out of hope, passion, obligation, interest, or some other motivation, are engaged in all the same.

I have shown how these ambivalent negotiations fall out of view because of the operations of certain market devices. Part of the reason this abstraction is successful is that the market seems to work irrespective of how strong or weak the motivations of its participants are. If the market works as designed, moreover, it may amplify their intentions even as it distorts them, building linkages with suppliers and consumers of energy, as well as with European and global efforts to address climate change. There may be only a few AD plants registered for ROCs, but this has invested them with greater renown as state-certified operations peddling virtual signs of a greater environmental purpose. This is why Sloan is invited to international conferences where he describes his digester as "a good step on the way to where agriculture needs to be" and why Nelson's farm attracts so many visitors that he has begun charging anywhere from $£ 200$ to $£ 1,000$ for offering tours of his digester.

Green certificates may yet become something more meaningful. Thinking more optimistically, they could represent a way of linking imperfect desires to "do something" to broader fields of engagement than the household or marketplace. Like more widely circulated and more trusted forms of money, green certificates could hold the potential to bridge the impersonal and the personal (Hart 2007) in the transformation of energy economies. But if this requires scaling up a model of an oblivious self with simple desires, it is not likely to reflect the reality of policy implementation on the ground. In this way, focusing on the ambivalent actions and disavowals associated with emerging green markets poses a challenge to the specter of Homo economicus in social theories of action. Behind the depiction of Hirschmann's unrealized intentions or Weber's unintended consequences lurks 
the presumption of a desiring ego cursed with imperfect knowledge: the economic subject ignorantly hopes for something to happen that never does, or something they never intended to happen unexpectedly occurs. The ways in which ROCs or carbon credits are accounted for, by contrast, reveals the significance of imperfect desire for conducting and reflecting on economic action.

By highlighting the motivations of emerging markets I have attempted to draw attention to the technicalities and facts associated with fantasies of a desired reconciliation of capitalist and ecological values. In his account of bioprospecting in the ocean, Stefan Helmreich captures a related concept with the term blue-green capitalism, meaning "where blue stands for speculative sky-high promise and green for a belief in biological fecundity" (2008:107). Such speculative wonder at the possibilities of nature can just as quickly turn to sublime horror at the thought of losing or destroying that nature - an "alternation between promise and apocalypse" (Helmreich 2008:15). Both images are crucial in contemporary syntheses of green capitalism - a fundamental fantasy leaving many ambivalent or frustrated while regulators and experts seek to motivate and understand them.

\begin{abstract}
This article examines efforts to reconcile capitalist and ecological values, focusing in particular on the instruments and ideologies that pervade the United Kingdom's developing renewable energy sector. In keeping with neoliberal models of economic knowledge and practice, renewable energy instruments target the motivations of individuals by using incentive programs to reach environmental policy goals. The argument focuses especially on the way newly implemented market devices shape and represent the motivations of energy producers, suppliers, and traders. The centerpiece of the U.K. government's initiative is the creation of an artificial market in renewability, bought and sold as a virtual commodity. Although the realities of economic motivation complicate the practical implementation of the renewable market, these are represented as isolated and self-interested "exchanges" by market devices, providing policymakers and their critics with partial yet authoritative accounts of renewable policy, premised on narrow and contested assumptions about economic motivation and action. [markets, STS, renewable energy, finance, climate change]
\end{abstract}

\title{
NOTES
}

Acknowledgments The research for this article was supported through the Waste of the World Programme and the ESRC (RES 000-23-0007). I would also like to thank Anne Allison and Charles Piot, as well as the two anonymous reviewers for their invaluable assistance with the completion of this article. I owe a debt of gratitude to Catherine Alexander, Angie Bywater, David Graeber, Keith Hart, Alan Metcalfe, Colin Murchie, Tony Sharkey, and most of all, James Murcott, for helpful commentary and contributions to the project. 
1. Insofar as such approaches cling to a vision of a profitable and sustainable business, the perspective from Marxian ecology could suggest that they cannot solve the contradictions between capitalism and ecology and may deepen them even further.

2. The names of all individuals and businesses have been changed to preserve their anonymity, with the exception of Murcott, who preferred it otherwise.

3. But there is a great deal excluded from the diagram as well. In the case of both German tariff and U.K. quota programs, the role of consumers in subsidizing rematerialization may remain obscure, buried within energy bills as unexplained fees.

4. Although hunting foxes with dogs in the British countryside has historically been a pursuit of social elites, it is an established ritual among farmers and became more socially inclusive in the late 20th century (see Milbourne 2003).

5. I was initially so taken by these arguments, in fact, that I attempted to persuade Nelson and his wife to sell their ROCs at auction to get a better price.

Editors' Note: Cultural Anthropology has published a number of articles on markets and economies. See, for example, Smoki Musaraj's "Tales from Albarado: The Materiality of Pyramid Schemes in Postsocialist Albania” (2011), Douglas R. Holmes's “Economy of Words” (2009), and Robert J. Foster's "The Work of the New Economy: Consumers, Brands, and Value Creation” (2007).

Cultural Anthropology has also published a number of articles on environmental politics, including Thomas Pearson's “On the Trail of the Living Modified Organisms: Environmentalism within and against Neoliberal Order" (2009), Marina A. Welker's "'Corporate Security Begins in the Community': Mining, the Corporate Social Responsibility Industry, and Environmental Advocacy in Indonesia" (2009), and Joseph Masco's "Mutant Ecologies: Radioactive Life in Post-Cold War New Mexico" (2004).

\section{REFERENCES CITED}

Agnolucci, Paolo

2007 The Effect of Financial Constraints, Technological Progress and Long-Term Contracts on Tradable Green Certificates. Energy Policy 35:3347-3359.

Akin, David, and Joel Robbins, eds.

1999 Money and Modernity: State and Local Currencies in Melanesia. Pittsburgh: University of Pittsburgh Press.

Barry, Andrew

1993 The European Community and European Government: Harmonization, Mobility and Space. Economy and Society 22(3):314-326.

Bloch, Maurice, and Jonathan Parry, eds.

1989 Money and the Morality of Exchange. Cambridge: Cambridge University Press.

Callon, Michel

2009 Civilizing Markets: Carbon Trading between In Vitro and In Vivo Experiments. Accounting, Organization and Society 34:535-548.

Callon, Michel, ed.

1998 The Laws of the Markets. Oxford: Blackwell.

Clark, Brett, and Richard York

2005 Carbon Metabolism: Global Capitalism, Climate Change, and the Biospheric Rift. Theory and Society 34(4):391-428.

Foster, John Bellamy

2000 Marx's Ecology. New York: Monthly Review.

Foster, Robert J.

2002 Ecology against Capitalism. New York: Monthly Review.

2007 The Work of the New Economy: Consumers, Brands, and Value Creation. Cultural Anthropology 22(4):707-731. 
Graeber, David

2011 Debt: The First 5000 Years. New York: Melville House.

Guyer, Jane

2004 Marginal Gains: Monetary Transactions in Atlantic Africa. London: University of Chicago Press.

Hart, Keith

2007 Money Is Always Personal and Impersonal. Anthropology Today 23(5):12-16.

Hawken, Paul, Amory B. Lovins, and L. Hunter Lovins

1999 Natural Capitalism: The Next Industrial Revolution. New York: Little, Brown.

Hayden, Cori

2003 From Market to Market: Bioprospecting's Idioms of Inclusion. American Ethnologist 30(3): 1-13.

Helmreich, Stefan

2008 Alien Ocean: Anthropological Voyages in Microbial Seas. Berkeley: University of California Press.

Hirschmann, Albert O.

1977 The Passions and the Interests. Princeton: Princeton University Press.

Holmes, Douglas R.

2009 Economy of Words. Cultural Anthropology 24(3):381-419.

Holmes, Douglas, and George Marcus

2006 Fast Capitalism: Para-Ethnography and the Rise of the Symbolic Analyst. In Frontiers of Capital: Ethnographic Reflections on the New Economy. M. S. Fisher and G. Downey, eds. Pp. 33-57. Durham, NC: Duke University Press.

Keane, Webb

2008 Market, Materiality and Moral Metalanguage. Anthropological Theory $8(1): 27-42$.

Kovel, Joel

1999 The Justifiers: A Critique of Julian Simon, Stephan Schmidheiny, and

Paul Hawken on Capitalism and Nature. Capitalism, Nature, Socialism $10(3): 3-36$.

Lemon, Alaina

1998 "Your Eyes Are Green Like Dollars": Counterfeit Cash, National Substance, and Currency Apartheid in 1990s Russia. Cultural Anthropology 13(1):22-55.

MacKenzie, Donald

2009 Material Markets: How Economic Actors Are Constructed.

Oxford: Oxford University Press.

Masco, Joseph

2004 Mutant Ecologies: Radioactive Life in Post-Cold War New Mexico. Cultural Anthropology 19(4):517-550.

Maurer, Bill

2005 Mutual Life, Limited: Islamic Banking, Alternative Currencies, Lateral Reason. Princeton: Princeton University Press.

2007 Incalculable Payments: Money, Scale, and the South African Offshore Grey Money Amnesty. African Studies Review 50(2):125-138.

Meyer, Niels, and Anne Louise Koefoed

2003 Danish Energy Reform: Policy Implications for Renewables. Energy Policy 31:597-607.

Milbourne, Paul

2003 Hunting Ruralities: Nature, Society and Culture in "Hunt Countries" of England and Wales. Journal of Rural Studies 19(2):157-171.

Mitchell, Catherine

2000 The England and Wales Non-Fossil Fuel Obligation: History and Lessons. Annual Review of Energy and the Environment 25;285-312. 
Mitchell, Catherine, Dierk Bauknecht, and Peter M. Connor

2006 Effectiveness through Risk Reduction: A Comparison of the Renewable Obligation in England and Wales and the Feed-In System in Germany. Energy Policy 34:297-305.

Mitchell, Timothy

2005 The Work of Economics: How a Discipline Makes Its World. European Journal of Sociology 46(2):297-320.

2009 Carbon Democracy. Economy and Society 38(3):399-432.

Miyazaki, Hirokazu

2003 The Temporalities of the Market. American Anthropologist 105(2):255265.

Musaraj, Smoki

2011 Tales from Albarado: The Materiality of Pyramid Schemes in Postsocialist Albania. Cultural Anthropology 26(1):84-110.

O'Connor, James

1997 Natural Causes: Essays in Ecological Marxism. New York: Guilford.

Ofgem

2009 Renewables Obligation: Annual Report 2007-2008. London: Office of Gas and Electricity Markets.

Ong, Aihwa

2006 Neoliberalism as Exception: Mutations in Citizenship and Sovereignty. Durham, NC: Duke University Press.

Pearson, Thomas

2009 On the Trail of the Living Modified Organisms: Environmentalism within and against Neoliberal Order. Cultural Anthropology 24(4):712-745.

Pocock, J. G. A.

1975 The Machiavellian Moment: Florentine Political Thought and the Atlantic Republican Tradition. Princeton: Princeton University Press.

Poovey, Mary

1998 The History of the Modern Fact. London: University of Chicago Press.

Rajan, Kaushik Sunder

2006 Biocapital: The Constitution of Post-Genomic Life. Durham, NC: Duke University Press.

Riles, Annelise

2006 Real Time: Unwinding Technocratic and Anthropological Knowledge. In

Frontiers of Capital: Ethnographic Reflections on the New Economy. M. S.

Fisher and G. Downey, eds. Pp. 86-107. Durham, NC: Duke University Press.

Ringel, Marc

2006 Fostering the Use of Renewable Energy in the European Union: The Race between Feed-In Tariffs and Green Certificates. Renewable Energy 31:1-17.

Sodikoff, Genese

2007 An Exceptional Strike: A Micro-History of "People versus Park" in Madagascar. Journal of Political Ecology 14;10-33.

Toke, David

2005 Are Green Electricity Certificates the Way Forward for Renewable Energy? An Evaluation of the United Kingdom's Renewables Obligation in the Context of International Comparisons. Environment and Planning C 23:361-374.

Welker, Marina A.

2009 "Corporate Security Begins in the Community": Mining, the Corporate Social Responsibility Industry, and Environmental Advocacy in Indonesia. Cultural Anthropology 24(1):142-179. 